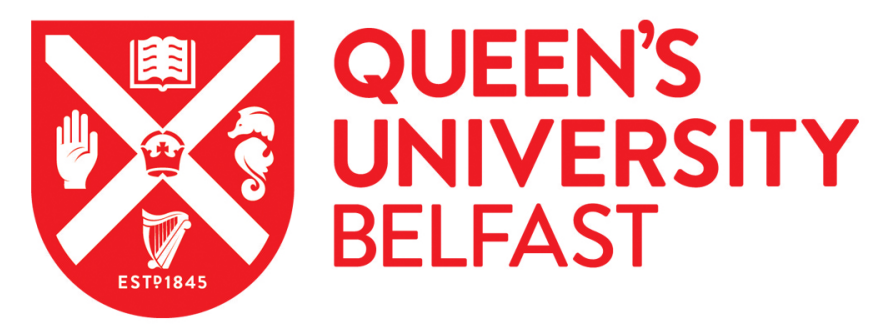

\title{
Island risks and the resilience of a prehistoric civilization
}

McLaughlin, T. R., Stoddart, S., \& Malone, C. (2018). Island risks and the resilience of a prehistoric civilization. World Archaeology. https://doi.org/10.1080/00438243.2018.1515656

\author{
Published in: \\ World Archaeology
}

Document Version:

Peer reviewed version

Queen's University Belfast - Research Portal:

Link to publication record in Queen's University Belfast Research Portal

Publisher rights

(c) 2018 Informa UK Limited, trading as Taylor \& Francis Group. This work is made available online in accordance with the publisher's policies. Please refer to any applicable terms of use of the publisher.

\section{General rights}

Copyright for the publications made accessible via the Queen's University Belfast Research Portal is retained by the author(s) and / or other copyright owners and it is a condition of accessing these publications that users recognise and abide by the legal requirements associated with these rights.

Take down policy

The Research Portal is Queen's institutional repository that provides access to Queen's research output. Every effort has been made to ensure that content in the Research Portal does not infringe any person's rights, or applicable UK laws. If you discover content in the Research Portal that you believe breaches copyright or violates any law, please contact openaccess@qub.ac.uk. 


\section{Island risks and the resilience of a prehistoric civilization}

T. Rowan McLaughlin

School of Natural and Built Environment, Queen's University Belfast, BT7 1NN, UK

Corresponding author, r.mclaughlin@qub.ac.uk

Simon Stoddart

Department of Archaeology, University of Cambridge, CB2 3ER, UK

Caroline Malone

School of Natural and Built Environment, Queen's University Belfast, BT7 1NN, UK 


\title{
Island risks and the resilience of a prehistoric civilization
}

\author{
Abstract: Resilience in the face of uncertainty is a universal issue, but of particular \\ concern for small islands where climate change and accelerated sea level change \\ are current worries. This paper investigates the issues of resilience and uncertainty \\ in the case of prehistoric Malta, which at face value presented a natural \\ environment fraught with many risks. We survey these dangers, especially the \\ potential damage to food crops caused by soil erosion, to which the islands of \\ Malta are particularly exposed. The prehistoric inhabitants of the islands \\ nonetheless coped with uncertainty with enormous success as recent new \\ excavations and radiocarbon dating have revealed that the elaborate periods of \\ monument maintenance, for which the Maltese islands are widely famed, has a \\ duration of some 1200 years.
}

Keywords: Malta, agriculture, 'Temple Period', erosion, resilience, islands

\section{Introduction}

The Maltese islands in the Central Mediterranean (Figure 1) are a paradise of sorts. This is an environment of virtually unlimited sunshine, relatively fertile carbonate soils, a diverse landscape rich in niche features, and a surprising amount of fresh water held in small rainwater catchments by an impermeable stratum of clay in the limestone geology (Pedley and House 1976). However, the islands are also an environment of violent seasonal thunderstorms and winds, thin soil cover, and limited space (totalling $316 \mathrm{~km}^{2}$ ). Communications are restricted too, since the islands are separated from Sicily by at least $80 \mathrm{~km}$ of sea. These appear to be longue durée qualities of the islands in their 8000 year human story that have been faced to a greater or lesser degree by all islanders regardless of period. Between $3800 \mathrm{BC}$ and $2400 \mathrm{BC}$, as much of Southern Europe entered the Copper 
Age, an unparalleled set of sophisticated cultural developments took place on the Maltese islands. These developments involved the construction of architecturally complex megalithic buildings, elaborate collective burial practices in hypogea, and the emergence of distinctive traditions in figurative and decorative art, locally identified as the 'Temple Culture'. The archaeological traces of these activities have retained a power that dazzles and amazes the modern observer. This achievement is the so-called Maltese 'Temple Period' and it can be distinguished from contemporary Copper Age archaeological cultures in Italy and elsewhere on the basis of its distinctive material culture and the apparent absence of metallurgy. Equal to the scale of the cultural vibrancy is the longevity of these traditions, because megalithism, in particular, can be traced over a span of some 1200 years. Few of the defining characteristics of the 'Temple Period' are carried forward very far into the Bronze Age, which has long prompted questions of why these distinct traditions emerged in Malta in the first place, and why they so suddenly disappeared. The 'Temple Culture' developments in the fourth and third millennium $\mathrm{BC}$ appear to be a distinct response of social resilience to the longue durée characteristics of the islands. In this article, we approach these questions from the perspective of the risks that the prehistoric inhabitants of Malta faced from uncertainties in their natural environment, and how these issues were mitigated, successfully in the main, by successive generations of prehistoric farmers in the 'Temple Period'. The archaeological, palaeoecological and palaeo-dietary data we discuss come largely from a major new multidisciplinary project (FRAGSUS) that has been studying the fragility and sustainability of the Maltese islands (Malone, Brogan, et al. in press).

The islands of Malta provide an excellent example of the interface between physical and social resilience in response to vulnerability and risk. The study of resilience is derived from ecology, where it is defined as the characteristic of ecological systems to withstand disturbances from their external conditions and influences (Holling 1978). We can measure 
the physical capacity for resilience of the prehistoric inhabitants of Malta in the human remains: the levels and tempo of mortality, the degree of attrition on their joints and dentition. Equally, we can assess the capacity of their communities to achieve social resilience, acting together as communities, centred on their water and soil-rich club houses, traditionally designated 'temples'. Such an approach replaces the hierarchical schemes formerly proposed for the Maltese islands (Renfrew 1973) and suggests a much more heterarchical, sometimes factional, internal cooperation and cohesion that allowed these communities to work together for a period of more than 1200 years (cf. Bonanno et al 1990). By about $2400 \mathrm{BC}$ however, a combination of environmental changes, temptations towards hierarchical control and greater connectivity with the outside world seem to have persuaded the prehistoric inhabitants to adopt different modes of resilience, and perhaps new models of socio-economic practice offered by external Bronze Age worlds.

The environmental changes in question are the ' 4.2 kya event', a set of changes to climate and weather patterns that affected much of the globe around $2200 \mathrm{BC}$ (Bond et al. 2001). This event evidently played a demonstrable role in cultural collapse or change in semiarid parts of the world, (for example in Mesopotamia) (Cullen et al. 2000), Egypt (Stanley et al. 2003), the Indus Valley (Staubwasser et al. 2003) and China (Liu et al. 2012)). Although the event affected parts of the Mediterranean region differently, the balance of evidence suggests that Malta would have been made more arid as a consequence and evidence from Sicily indicates that the event occurred during a longer-term trend toward warmer and drier summer weather in the region between c. 5000 and 1500 BC (Curry et al. 2016).

\section{Risks and strategies}


Whatever the special and unique life-ways that emerged in Malta, the prehistoric inhabitants of the islands were first and foremost agriculturists. Although there is evidence for contact between Malta and the outside Mediterranean world during the 'Temple Period', the absence of large sea-going vessels restricted the amount of bulk materials that could be imported or exported. Successful agriculture therefore required a self-sustaining pattern of local resource exploitation. This local dependence is true in any relatively closed or isolated system such as islands, in contrast to colonies in new frontiers, which arguably can be scaled up to the global economy of today. Mitigating risks and adapting to local misfortune were the key activities that enabled the success of prehistoric Malta. The risks that the environment poses in Malta can be identified by examining the current environmental context of human life and agriculture on the islands in terms of the traditional elemental and universal themes of weather, water, fire and earth.

\section{Fire}

Maltese summers are exceedingly long and dry, and like many other parts of the Mediterranean, introduce risks of wild fire from July to November (Moreira et al. 2011). Sediment cores extracted from the valley fills contain layers of charcoal dating to as long ago as $8000 \mathrm{BC}$, before arrival of people (French et al. in preparation). These charcoal layers were caused by natural outbreaks of wildfire, but similar concentrations of charcoal have been found in layers dating to the Early Neolithic, specifically in the period 5500 to $5000 \mathrm{BC}$, representing the early clearance of land. In the 'Temple Period', fire becomes surprisingly elusive from the palaeoecological and archaeological records, despite long term trends toward greater aridification (French et al. 2018; Curry et al. 2016). This can be explained by the significantly reduced amount of trees and scrub land over much of the Maltese islands, and a somewhat damper climate (Carroll et al. 2012). These changes are relative, and the overall risk from fire was nonetheless high; control over it was symbolised in the megalithic sites, the 
"temple" club houses of collective feasting, where the response was to contain fire within particular parts of the structures. These so-called 'fire pits' were situated deep on the right side within the megalithic buildings, contrasted, in structuralist terms, with water on the lefthand side (Malone 2007). That the elemental and destructive force of fire could be so deeply contained within the megalithic buildings is a symbol of triumph over the forces of the natural world. The dangers of the wild, natural world were tamed and constrained by impressive cultural constructions. Fire was put to work towards collective feasting as part of celebratory events that signalled the mitigation and monitoring of risk in a vulnerable landscape.

\section{Seas and storms}

The Maltese Islands are a remnant of a once much larger peninsula of southern Sicily gradually drowned and eroded by rising sea levels since the last glacial maximum some 21,000 years ago (Lambeck et al. 2011). Sea levels were still rising quite rapidly when Early Neolithic colonists first made their way to Malta shortly after $6000 \mathrm{BC}$, but by the 'Temple Period', the coastline of the islands had assumed its approximate current shape (Furlani et al. 2013). In this context, memories of a shrinking world may have been retained in the myths and memories of the islanders (Stoddart 2015). Storms throughout recorded history have caused much damage - a recent event was the collapse of the Azure Window (a renowned tourist attraction on Gozo) in 2016. The north coast of the island, where, according to tradition, St Paul was shipwrecked, is particularly exposed. One megalithic site, 'Xrobb IlGhagin', stands on a headland undercut by the waves and has already partly collapsed into the sea, and starkly illustrates the considerable amount of land lost to coastal erosion in the 5000 years since the 'Temple Period'. However, such long drawn-out processes pose little risk to day-to-day life. Sea spray can damage crops, and indeed, land prone to such damage in Malta has a demonstrated lower value (Alberti, Grima, and Vella 2018). These factors likely 
engendered a cautious approach to the sea, although we cannot know details of this attitude in the past. Maritime motifs feature only occasionally in the material culture of the 'Temple Period', most prominently the fish engravings found in the 'temple' of Bugibba and fish figurines from Hal Saflieni hypogeum (Evans 1971). From stable isotope sudies we know that during the 'Temple Period' fish did not feature prominently in the diet (Richards et al. 2001; Stoddart et al. 2009). This trend is in line with other prehistoric agricultural economies elsewhere, and even among Mesolithic hunter-gatherers of the region, who depended little on marine resources (e.g. Mannino et al. 2012). It seems that the volatile and unforgiving nature of the central Mediterrean sea led to a long term disinclination toward exploiting its potential riches for food. Instead, the agriculturists of the 'Temple Period' invested as much as possible on dry land, and took this task to levels of success rarely achieved by other Neolithic populations. However, that success too, was prone to damage from storms and water through soil erosion.

\section{Soil and rainwater erosion}

Soil rainwater erosion is the process that carries soil and sediment from the land via surface runoff and storm events that incise channels into soft ground. Its severity is influenced by soil properties, particularly the binding qualities of the organic fraction, the degree of vegetative cover, rainfall intensity, and the length and steepness of the terrain. Soil erosion is one of the most important processes that have shaped the evolution the landscape of the Mediterranean during the Holocene (Butzer 2005). This is because Mediterranean environments have high rainfall intensities, fragile, slow-accumulating soils that are low in organic matter, steep slopes and a sparse vegetation (García-Ruiz et al. 2013). Severe erosion events during the Bronze Age and later have been detected throughout Mediterranean Europe (Dotterweich 2008). In Malta, full details of the erosional history are not known but the potential for soil erosion is particularly high, given the pluvial autumn storms, steeply-incised valleys and the 
long history of deforestation (Carroll et al. 2012). The landscape bears many indicators that erosion has been a major problem in the past, such as extensive exposures of bare rock in barren uplands (Figure 2), and accumulations of depths $(10 \mathrm{~m}+)$ of alluvial material in the valley bottoms (Carroll et al. 2012). From an agricultural perspective, soil erosion can be doubly catastrophic in terms of loss of land and damage to crops. Today, damage from soil erosion in Europe costs an estimated $€ 1.25$ billion per annum (Panagos et al. 2018) and in Malta there has long been the need to compensate farmers for the sometimes total loss of their crops (Mitchell and Dewdney 1961). Soil erosion is most likely to occur during storms in the autumn months, when vegetation cover is at a minimum. Although the Mediterranean climate has changed somewhat since the 'Temple Period', the changes are not of sufficient magnitude to reduce significantly the risk of soil erosion, a point that can be made by surveying the erosive potential of many different modern-day European settings (Panagos et al. 2015). Despite the strongly season weather patterns in Malta, soil erosion remains an unpredictable phenomenon because a characteristic of the Maltese archipelago is that heavy rainfall is surprisingly regional within any given storm (Mayes 2001). Like other risks posed by the environment, erosion is a violent and chaotic event, contributing to an unstable landscape and an uncertain future for those who inhabit it. Geoarchaeological studies conducted as part of recent fieldwork have shown that this process was already well under way during the Neolithic (French et al. 2018).

Several mechanisms to mitigate the effects of soil erosion could have been developed in the 'Temple Period' in Malta. During recent centuries these mechanisms have taken the form of terracing, physical transportation of soil from place to place, and the synthesis of new soil from crushed rock and manure. Terracing in particular dominates the rural Maltese landscape, occurring virtually everywhere, and like the other strategies mentioned above, would in theory have been within the technological ability of prehistoric agriculturists, 
although direct archaeological evidence is elusive. Large walls resembling terraces and dating to the 'Temple Period' have been found in association with megalithic sites at Skorba, Ġgantija and Mnajdra (Evans 1971; Trump 1966), although it is more likely that these were part of the monumental setting of these sites, rather than having an agricultural function.

Recent excavations on Gozo at the Santa Verna and Ggantija 'temples' have unearthed field soils from the earlier Neolithic and 'Temple Period' and collected samples have been subjected to micromorphological analysis (French et al. in press; French et al. 2018). This study has demonstrated that the 'Temple Period' soils, in contrast to those of the earlier Neolithic, were quickly degraded, and lost their ability to retain moisture and nutrients, which would have reduced productivity and further amplified the effects of erosion. The micromorphological analysis revealed that the soils were artificially enhanced with the addition of domestic refuse represented by fine charcoal, fragments of bone and pottery. Manure too was a likely part of this process of augmentation. The laborious augmentation of soil is an act of maximising the limited resources available, and if extrapolated to the wider landscape, represents a prodigious investment of human capital in the soil.

The movement of soil from place to place is best evidenced in Malta by 'cart ruts' mysterious parallel pairs of linear striations in the bedrock often leading from valley bottoms to the hill tops. Their shape and form suggests the presence of a greater cover of soil in the past than exists today. The dating of the cart ruts is highly problematic, with a consensus view holding that they date to the Bronze Age. However, a 'Temple Period' date cannot be excluded, and in many ways fits the available data (cf. Evans 1971, 203). Their function is also open to interpretation, but they do seem to be directly associated with the movement of heavy bulk, be it soil, stone or water (Zammit 1928). An advantage for the upslope carrying of soil would be that it enhanced upland soils with phosphates from weathered lowland Globigerina beds (Alexander 1988) and improved agricultural returns. 
A number of subtle clues emerge from the examples discussed that suggest the people of prehistoric Malta were active in the formation of the physical landscape, and perhaps held the resources together in a way which enabled agriculture to succeed. All these clues point toward a relatively high human population density for the islands during the 'Temple Period', based on the sheer number of contemporary monuments (Renfrew and Level 1979). The astonishing quantities of pottery found all over the landscape during field survey, especially from earlier phases of the 'Temple Period' (Boyle 2014) further suggest a high population. A plausible number, based on the carrying capacity of the island in medieval times, is around 9000 persons, or approximately 2.8 people per $\mathrm{km}^{2}$ (cf. Bowen-Jones, Dewdney, and Fisher 1960; Renfrew and Level 1979). The energy required to undertake the maintenance activities described above, also points to a significant number of people prepared to engage in organised labour across the whole landscape. A model therefore emerges that implies the 'Temple' megaliths and associated ritual customs were megalithic 'club houses' or 'social resilience chambers', where collective action was celebrated in repetitive, highly structured and symbolic actions, reflected in the features common to all these megalithic sites (Table 1). As such the 'temples' were part of a much wider and economically vital system of organised behaviour that revolved around the natural cadence of the agricultural year (Barratt et al. in press). This idea is supported by the seasonal, rather than precise calendrical, alignments of the monuments (Barratt 2018), and by the large accumulations of agricultural products, together with the necessary ceramic and stone containers for food that enabled largesse to be offered to both divinities and humans. It was perhaps the related themes of soil, erosion, irrigation (given the relatively low levels of rainfall) and fertility that were foremost in the minds of the 'Temple' builders, whose otherwise esoteric ritual life formed but one outlet for the social complexity, co-operation and interconnectedness that Malta's ancient inhabitants depended upon. 


\section{Resilience}

Naturally resilient ecological systems recover from setbacks. Static equilibrium is eschewed by such systems, and instead their defining characteristic is one of dynamic equilibrium, where the system is able to return to a near-optimal state following a period of disruption. What drives ecological resilience is a capacity for adaptation, borne from the variability of biological traits within a given community, or a community's ability to migrate and disperse. From an evolutionary perspective, the process of migration can itself enhance the degree of trait variation. Parallels with cultural evolution are not difficult to make, as human biological and cultural diversity is putatively driven by the drawing together of people and influences from near and far.

It seems beyond doubt that the 'Temple Period' people of Malta had developed an ecologically resilient agricultural and social system, since by definition, resilience is the set of traits that enable stability over the long term. Barnett (2001) collates six interrelated traits together from previous research that apply to human systems using principles common to both resilient societies and resilient ecologies. These are:

(1) the homeostasis principle, which states that the system is maintained via feedbacks or internal channels of communication

(2) the omnivory principle states that shocks to the system are mitigated by a wide resource base and diversification in how resources are consumed

(3) the high-flux principle, which states that rapid movement of resources through a system effectively maximises the amount of resources available

(4) the flatness principle, which holds that low hierarchy in a system is more resilient because overly hierarchical systems are inflexible and cannot cope with shock 
(5) the buffering principle, which states that surplus or stored resources create resilience in times of need

(6) the redundancy principle, where the vital functions of a system overlap, providing continuity during times of stress and further capacity for adaptation.

Many, but not all, of these principles are recognizable in the archaeological record of 'Temple Period' Malta. We have evidence for a creative social resilience, whereby society maintained its defining characteristics despite some episodes of cultural change and pressure from the environment (cf. Bollig 2014, 263-265). This drew its cohesion from distinctive social groupings that we detect in the 'club houses temples', working closely together in a fragile environment and celebrating their enduring success with substantial feasts and memorialisation of past achievements and reliable tempos within a changing world (Malone 2018; Barratt et al. in press). Evidence that the agricultural resource base was wide and diverse is clear from the archaeobotanical record; new excavations at the 'Temple Period' settlement of Tac்-Cawla on Gozo have unearthed rich assemblages of wheat, barley, lentil and pea, occasionally occurring together in the same context (Malone, McCormick, et al. in press). There is also palynological evidence of exploitation of olive during the period (Carroll et al. 2012). These taxa produced a diverse resource base, which had the potential for buffering and redundancy typical of a resilient system. Cereals and legumes were seemingly grown together, which would have had the beneficial effects of improving fertility and reducing the potential for soil erosion (Wang et al. 2014). On the other hand, animal bone assemblages from all contexts are not diverse, but instead dominated by caprine bones with lesser numbers of pig and cattle - although the presence of elderly animals suggests dairying (Malone, McCormick, et al. in press). This is an inherently resilient strategy because it widens the available resource base, and provides opportunity to store protein-rich food in the form of cheese and butter. The enriched ${ }^{15} \mathrm{~N}$ content of 'Temple Period' human remains 
seems compatible with a diet rich in dairy (Richards et al. 2001). Intensive horticulture, combined with more extensive stock rearing of goats, has been a long-term strategy of resilience in the Maltese islands that uses the fragmented micro-niches that exist even in a small island, to the maximum advantage of the inhabitants (Bowen-Jones, Dewdney, and Fisher 1960).

The best archaeological representation of early Malta's resilient foodways is found in the prehistoric pottery from 'Temple Period' sites. 'Temple Period' pottery exists in an unparalleled array of forms manufactured at many scales, but storage vessels are commonly found amongst them (Evans 1971, 212-214). Especially during early and late phases of the 'Temple Period' (around 3600 and 2500 BC respectively), significant numbers of large ( $>30 \mathrm{~cm}$ diameter) pots were produced (Figure 3), (jars and flasks in particular that could be closed or sealed) and this hints at an economy where storage and/or merchandise featured largely. These traits exemplify the buffering and flux principles of resilience. Reliance on storage was continued and actually expanded in the Middle Bronze Age (Borg in-Nadur phase), when large subterranean stores were dug out the bedrock under fortified settlements. These pits or 'silos' were often greater than $2 \mathrm{~m}$ in diameter and depth, and lined with clay; excavations of their contents has revealed large quantities of cereal grains (Evans 1971, 171) and midden material associated with intense domestic activity (Malone, McLaughlin, and Stoddart in preparation). The limestone geology of the islands lends itself to food storage underground and indeed similar storage pits were dug in Malta during the Knights period, a practice that intensified in response to experiences during the great siege of 1565 (Hyde and Daubeny 1960).

Pottery was used creatively and imaginatively in the display and distribution of food within the Neolithic 'club house temples'. Vessels of great decorative variety seem to have represented complex dining rituals and practices, and these ceramics were the containers and 
eating, drinking and serving vessels that fostered cultural identity and enhanced cooperation at key celebratory moments in the agricultural cycle. Most notably, going on the alignment of some of the monuments, this was probably at the winter solstice, recalling the power of the land to reawaken with the impending spring (Barratt et al. in press).

It is perhaps reductive to look too closely at the incomplete archaeological data for confirmatory evidence of resilience. Rather, the ecological model of resilience theory can be used to model what we do not yet know about how Maltese society functioned. The principle of flatness or low hierarchy is at odds with established views of the Maltese 'Temple Period' culture, a view that envisages a society dependent upon a 'priestly' elite (Renfrew 1973; Sagona 2015). Modern ethnography (Boissevain 1969) also suggests alternative factional and cooperative models which we intimated in earlier work (Bonanno et al. 1990). More recent evidence of cooperative feasting in 'temple' club houses reinforces this pattern of cooperation rather than domination (Malone 2018). A view of 'Temple Period' society as having a more egalitarian or communal power structure could be more realistic than the "priest" model, and this view resonates with the idea that people in ancient Malta needed cooperation and community interdependence to bring stability to an otherwise fragile, eroding island world.

\section{Conclusions: human effort as the binding force}

In the 'Temple Period', which was contemporaneous with the Copper Age elsewhere in southern Europe, there is now good archaeological evidence that the 'Temple Culture' was relatively stable for centuries, and sites such as the megalithic 'temple' structures remained in-use, modified but not re-designed for centuries, and there are stylistic and artistic motifs common to the material culture over a long period. It is tempting to see these Neolithic 
islanders as people who clearly understood their place in an environment which was inherently unpredictable, and comprehended the dynamics of their social-ecological farming system. The people invested heavily in their social sphere -- monumentalised by stone architecture and figurative art. With time, this cultural activity created permanent places and enduring ideologies that counterbalanced the constraints of a fragile and eroding landscape. The tendency towards relative stability in culture over the longer-term (homeostasis) is one of the defining characteristics of resilience.

The key aim of our ERC-funded project has been to answer simple but ambitious questions about the scale of human impact in Malta, how complex lifeways were sustained, how agriculture worked, when migration occurred, and how the 'Temple Period' culture 'collapsed' (Malone, Brogan, et al. in press). The answers to these questions are various, but they centre around recurring themes of co-operation, resource management and resilience. Initially agriculture was performed in the $6^{\text {th }}$ millennium BC by Early Neolithic colonists who drew on centuries of ancestral experience of agricultural practice in similar landscapes. That experience gave them the confidence to make a life in otherwise liminal Malta during a time of expansion and boom. Although initially successful, $6^{\text {th }}$ millenium ecological changes to the landscape were irreversible, and after a few centuries, during a time of evident contraction in the wider world (Shennan et al. 2013), the settlement of Malta faltered. Occupation seems to have reduced to the level of insignificance for almost a millennium. When large numbers of people returned in the early $4^{\text {th }}$ millennium BC, they faced yet more challenges - the moist forest soils available to earlier people were gone, and in their place existed an oxidised and eroded landscape. The cultural fluorescence that occurred in this context was one where place and materiality assumed great importance, and this fluorescence (the "Temple Culture") has created an enduring monumentalised archaeological legacy. 
Comparisons can be drawn between 'Temple Period' Malta and those cultures that existed before and after. During later times, the demographic parameters of Malta changed. From the Bronze Age onwards Malta became less isolated culturally and economically, and food production was less of a life-or-death issue for entire communities. With the onset of the external Bronze Age in Malta, new forms of social resilience became possible, as the resources were scaled up by greater connectivity with the outside world. New navigational skills and greater numbers of people offered new opportunities that in turn, were enabled by new forms of intensification that may have included terracing, arboreal crops, and for the first time the import of foodstuffs on an increasingly substantial scale. These are the conditions that much later were greatly consolidated under the 16 th -17 th Century Knights, who drew on rents from all over Europe, whilst under British Rule from 1800 Malta became part of an even larger system. The modern integration of Malta within the European Union is part of the same strategy today.

Perhaps the most significant result from recent research is the sense of constant change in the more distant past - as revealed through dating, caused by harmony and discord in the natural and cultural forces that shape the world. The island setting of Malta is a microcosm of larger scale worlds, showing that with enough effort, human life can flourish anywhere, but nowhere are guarantees given that it will endure. The people of the 'Temple Period' were resilient in the face of environmental stress in a way in which their earlier Neolithic forebears were not. Early Neolithic culture had all but extinguished itself in Malta by the time the first 'Temple' Builders arrived. The evidence for this can be found in the complete break in pottery styles and fabrics (Trump 1966), a reduced level of cereal pollen in sediment cores and little detectable archaeological activity at sites subjected to intensive programmes of radiocarbon dating (French et al in preparation). This was despite many natural advantages, especially the early soils of Malta, which were richer, damper, better- 
vegetated and less prone to erosion than those of the 'Temple Period' (French et al. in press; French et al. 2018). The apparent 'boom and bust' phenomena seen elsewhere in Neolithic Europe (Shennan et al. 2013) certainly applied to earlier Neolithic Malta, whereas the stable pattern of 'Temple Period' settlement seems to strongly contrast with these phenomena. The Maltese people had found a solution through creative resilience that was as much social as it was physical. That said, there are hints that some centuries within the 'Temple Period' are less visible archaeologically than others, and there remains a possibility that the overall scale of the society fluctuated. Even if this fluctuation is borne out, the long-lived nature of the architectural idioms unique to the 'Temple Period' and the continuity in pottery forms, demonstrate a notably resilient culture that can be traced over some 1200 years.

Ecological theory can also help interpret a potentially problematic argumentum ex silentio that the gaps in the archaeological record in Malta equate to a hiatus in settlement or a phase of much reduced activity. As discussed above, migration is a strategy adopted by many animals in response to stress, and in Malta the 'gaps' in the record could simply signal that the society had moved elsewhere. Ecology therefore provides a useful way to structure explanations of why demography is more dynamic during some periods than others; when the energy or capital usually invested in one form of survival strategy is re-directed elsewhere.

Without a resilient society, the Maltese Islands and other isolated or 'closed-loop' places, were vulnerable to rapid environmental degradation. Feedback loops may operate on both natural and cultural variables, and can have damaging consequences. Loss of vegetation caused for example by drought, increases soil erosion and brings loss of fertility and yet more erosion. In this respect, it is significant that the 'Temple Period' developments in Malta took place against a backdrop of warmer, drier, summer conditions (Curry et al. 2016) which would have increased the risk of erosion in autumn. Alternatively, land pressure (caused perhaps by a rising population or by social inequality), can lead to poverty and poor 
management practice, degradation of the land, and yet more pressure. These feedback loops can cause stable, seemingly resilient systems to collapse quickly once 'tipping points' are reached, and the established technical and social adaptations can no longer cope with stress.

Many parallels can be drawn between Malta and Orkney (cf. Stoddart et al. 1999); two contemporary precocious island civilisations on the outer margins of Europe. One detail is that like Malta, the Orcadian Neolithic environment was somewhat physically unstable, because Orcadian settlements were located in expanses of mobile wind-blown sand. During the Neolithic and Bronze Age, the sands were stabilised and brought into arable production (Simpson et al. 2006). This example demonstrates that, perhaps partly as a consequence of island isolation, an agricultural triumph emerged to match the architectural achievements for which the peoples of prehistoric Malta and Orkney are justly famed. In Malta, we glimpse a prehistoric landscape not dissimilar to marginal farmland in parts of the developing world today, in northeast Africa for example (e.g. Nyssen et al. 2000; Nyssen et al. 2004). There, like in ancient Malta, steep terrain, erosion and drought are mitigated by human capacity for hard work and an awareness of the fine balance that exists between agricultural systems and the environment upon which such systems depend. In ancient Malta, bare hands brought life to bare rock, and stability to chaos, and the people won for themselves a resilient environment in which human capital was a crucial part.

\section{Acknowledgements}

We thank all our colleagues in the Fragsus Project for stimulating discussion on the themes touched upon in this paper, especially Charles French and Sean Taylor (soils), Chris Hunt, Lisa CoyleMcClung and Michelle Farrell (pollen), Nathan Wright (charcoal), Eóin Parkinson, Ronika Power and Bernardette Mercieca-Spiteri (human bones), Finbar McCormick (animal bones), Katrin Fenech and Patrick Schembri (invertebrates), Rory Flood (sediments and soil erosion), Jeremy Bennett and Gianmarco Alberti (landscapes), Alastair Ruffell (geology), and Tony Pace, Nathanial Cutajar, Nick Vella and Reuben Grima (archaeology). We extend warm thanks to two anonymous reviews, and the 
editors of this volume, whose comments helped us improve this paper. We acknowledge and Heritage

Malta and the Superintendance of Cultural Heritage, Malta for permission to undertake fieldwork in

Malta. Funding for the work has been provided by the European Research Council Advanced Grant

323727 “FRAGSUS”. (PI Caroline Malone).

\section{References}

Alberti, G., R. Grima, and N. C. Vella. 2018. "The use of geographic information system and 1860s cadastral data to model agricultural suitability before heavy mechanization. A case study from Malta." PLOS ONE 13 (2):e0192039. doi: 10.1371/journal.pone.0192039.

Alexander, D. 1988. "A review of the physical geography of Malta and its significance for tectonic geomorphology." Quaternary Science Reviews 7:41-53.

Barnett, J. 2001. "Adapting to Climate Change in the Pacific Island Countries: The Problem of Uncertainty." World Development 29:977-93.

Barratt, R., S. Stoddart, T. R. McLaughlin, and C. Malone. in press. "Celebrations in Prehistoric Malta." World Archaeology. doi: https://doi.org/10.1080/00438243.2018.1496029.

Barratt, R. P. 2018. "A unity 3D script for calculating solar alignment at the neolithic temples complex at Ggantija, Gozo." Journal of Archaeological Science: Reports 17:634-9. doi: https://doi.org/10.1016/j.jasrep.2017.12.012.

Boissevain, J. 1969. Hal Farrug: a village in Malta. New York: Holt, Rinehart and Winston.

Bonanno, A., T. Gouder, C. Malone, and S. Stoddart. 1990. "Monuments in an island society: the Maltese context." World Archaeology 22 (2):190-205.

Bond, G., B. Kromer, J. Beer, R. Muscheler, M.N. Evans, W. Showers, S. Hoffmann, R. Lotti-Bond, I. Hajdas, and G. Bonani. 2001. "Persistent solar influence on North Atlantic climate during the Holocene." Science 294:2130-6.

Bolling, M. 2014. "Resilience - Analytical Tool, Bridging Concept or Development Goal? Anthropological Perspectives on the Use of a Border Object." Zeitschrift für Ethnologie 139, 253-279.

Bowen-Jones, H, J. C. Dewdney, and W. B. Fisher. 1960. Malta: Background for Development. Durham: Department of Geography, Durham Colleges.

Boyle, S. 2014. The social and physical environment of early Gozo - a study of settlement and change. Queen's University Belfast: Unpublished Ph.D. thesis.

Butzer, K. W. 2005. "Environmental history in the Mediterranean world: Cross-disciplinary investigation of cause-and-effect for degradation and soil erosion." Journal of Archaeological Science 32 (12):1773-800. doi: 10.1016/j.jas.2005.06.001.

Carroll, F. A., C. O. Hunt, P. J. Schembri, and A. Bonanno. 2012. "Holocene climate change, vegetation history and human impact in the Central Mediterranean: evidence from the Maltese Islands." Quaternary Science Reviews 52:24-40. doi: http://dx.doi.org/10.1016/j.quascirev.2012.07.010.

Cullen, H. M., P. B. deMenocal, S. Hemming, G. Hemming, F. H. Brown, T. Guilderson, and F. Sirocko. 2000. "Climate change and the collapse of the Akkadian empire: Evidence from the deep sea." Geology 28 (4):379-82. doi: 10.1130/0091-7613(2000)28<379:CCATCO>2.0.CO;2.

Curry, B., P. D. Henne, F. Mesquita-Joanes, F. Marrone, V. Pieri, T. La Mantia, C. Calò, and W. Tinner. 2016. "Holocene paleoclimate inferred from salinity histories of adjacent lakes in southwestern Sicily (Italy)." Quaternary Science Reviews 150:67-83. doi: https://doi.org/10.1016/j.quascirev.2016.08.013.

Dotterweich, M. 2008. "The history of soil erosion and fluvial deposits in small catchments of central Europe: Deciphering the long-term interaction between humans and the environment - $A$ review." Geomorphology 101 (1-2):192-208. doi: 10.1016/j.geomorph.2008.05.023. 
Evans, J. D. 1971. The prehistoric antiquities of the Maltese islands. London: Athlone Press.

French, C., S. Taylor, R. McLaughlin, A. Cresswell, T. Kinnaird, D. Sanderson, S. Stoddart, and C. Malone. 2018. "A Neolithic palaeo-catena for the Xaghra Upper Coralline Limestone plateau of Gozo, Malta, and its implications for past soil development and land use." Catena 171:337-58. doi: https://doi.org/10.1016/j.catena.2018.07.039.

Furlani, S., F. Antonioli, S. Biolchi, T. Gambin, R. Gauci, V. Lo Presti, M. Anzidei, S. Devoto, M. Palombo, and A. Sulli. 2013. "Holocene sea level change in Malta." Quaternary International 288:146-57. doi: https://doi.org/10.1016/j.quaint.2012.02.038.

García-Ruiz, J. M., E. Nadal-Romero, N. Lana-Renault, and S. Beguería. 2013. "Erosion in Mediterranean landscapes: Changes and future challenges." Geomorphology 198:20-36. doi: 10.1016/j.geomorph.2013.05.023.

Holling, C. 1978. Adaptive environmental assessment and management. London: Wiley.

Hyde, M. B., and C. G. Daubeny. 1960. "A study of grain storage fossae in Malta." Tropical Science 2:115-6.

Lambeck, K., F. Antonioli, M. Anzidei, L. Ferranti, G. Leoni, G. Scicchitano, and S. Silenzi. 2011. "Sea level change along the Italian coast during the Holocene and projections for the future." Quaternary International 232 (1-2):250-7. doi: 10.1016/j.quaint.2010.04.026.

Liu, X., M. K. Jones, Z. Zhao, G. Liu, and T. C. O'Connell. 2012. "The earliest evidence of millet as a staple crop: New light on neolithic foodways in North China." American Journal of Physical Anthropology 149 (2):283-90. doi: 10.1002/ajpa.22127.

Malone, C. 2007. Structure, art and ritual in a Maltese Temple. . Paper presented at the Cult in Context, Magdalene College, Cambridge.

Malone, C. 2018. "Manipulating the bones: eating and augury in the Maltese temples." In Ritual, play, belief, edited by C. Renfrew, I. Morley and M. Boyd. Cambridge: Cambridge University Press.

Malone, C., C. Brogan, T. R. McLaughlin, and S. Stoddart. in press. "Small Island Sustainability and a case study for Malta." In ATTI della Convegno: "Ubi Minor". , edited by A. Cazzella, A. Guidi and F Nomi. Rome: Rivista Scienze dell'Antichità.

Malone, C., F. McCormick, R. McLaughlin, and S. Stoddart. in press. "Megaliths, people and palaeoeconomics in Neolithic Malta." In Megaliths, societies, landscapes: early monumentality and social differentiation in Neolithic Europe, edited by J. Muller and M. Hinz. Bonn: Dr. Rudolf Habelt Verlag.

Malone, C., T. R. McLaughlin, and S. Stoddart. in preparation. "Excavations of Maltese Prehistory." In. Cambridge: McDonald Institute.

Mannino, M. A., G. Catalano, S. Talamo, G. Mannino, R. Di Salvo, V. Schimmenti, C. Lalueza-Fox, et al. 2012. "Origin and Diet of the Prehistoric Hunter-Gatherers on the Mediterranean Island of Favignana (Ègadi Islands, Sicily)." PLOS ONE 7 (11):e49802. doi: 10.1371/journal.pone.0049802.

Mayes, J. 2001. "Rainfall variability in the Maltese Islands: changes, causes and consequences." Geography:121-30.

Mitchell, P. K., and J. C. Dewdney. 1961. "The Maltese climate and weather." Malta, a background for development:48-82.

Moreira, F., O. Viedma, M. Arianoutsou, T. Curt, N. Koutsias, E. Rigolot, A. Barbati, et al. 2011. "Landscape - wildfire interactions in southern Europe: Implications for landscape management." Journal of Environmental Management 92 (10):2389-402. doi: https://doi.org/10.1016/j.jenvman.2011.06.028.

Nyssen, J., J. Poesen, J. Moeyersons, J. Deckers, M. Haile, and A. Lang. 2004. "Human impact on the environment in the Ethiopian and Eritrean highlands - A state of the art." Earth-Science Reviews 64 (3-4):273-320. doi: 10.1016/\$0012-8252(03)00078-3. 
Nyssen, J., J. Poesen, M. Haile, J. Moeyersons, and J. Deckers. 2000. "Tillage erosion on slopes with soil conservation structures in the Ethiopian highlands." Soil and Tillage Research 57 (3):115-27. doi: https://doi.org/10.1016/S0167-1987(00)00138-0.

Panagos, P., C. Ballabio, P. Borrelli, K. Meusburger, A. Klik, S. Rousseva, M. P. Tadić, et al. 2015. "Rainfall erosivity in Europe." Science of The Total Environment 511:801-14. doi: 10.1016/j.scitotenv.2015.01.008.

Panagos, P., G. Standardi, P. Borrelli, E. Lugato, L. Montanarella, and F. Bosello. 2018. "Cost of agricultural productivity loss due to soil erosion in the European Union: From direct cost evaluation approaches to the use of macroeconomic models." Land Degradation \& Development 29 (3):471-84. doi: 10.1002/ldr.2879.

Pedley, H.M, and M.RWaugh House, B. 1976. "The Geology of Malta and Gozo." Proceedings of the Geologists' Association 87 (3):325-41.

Renfrew, A. C. 1973. Before Civilisation. London: Jonathan Cape.

Renfrew, A. C., and E. V. Level. 1979. "Exploring dominance: predicting polities from centers." In Transformations, Mathematical approaches to Culture Change, edited by C. Renfrew and K.L Cooke, 145-68. New York: Academic Press.

Richards, M. P., R. E. M. Hedges, I. Walton, S. Stoddart, and C. Malone. 2001. "Neolithic diet at the Brochtorff Circle, Malta." European Journal of Archaeology 4 (2):253-62. doi: 10.1177/146195710100400206.

Sagona, C. 2015. The Archaeology of Malta: From the Neolithic Through the Roman Period: Cambridge University Press.

Shennan, S., S. S. Downey, A. Timpson, K. Edinborough, S. Colledge, T. Kerig, K. Manning, and M. G. Thomas. 2013. "Regional population collapse followed initial agriculture booms in midHolocene Europe." Nature Communications 4, 2486. doi: 10.1038/ncomms3486

Simpson I. A., E. B. Guttmann, J. Cluett, and A. Shepherd. 2006. "Characterizing anthropic sediments in north European Neolithic settlements: An assessment from Skara Brae, Orkney." Geoarchaeology 21 (3):221-35. doi: 10.1002/gea.20101.

Stanley, J.-D., M. D. Krom, R. A. Cliff, and J. C. Woodward. 2003. "Short contribution: Nile flow failure at the end of the Old Kingdom, Egypt: Strontium isotopic and petrologic evidence." Geoarchaeology 18 (3):395-402. doi: 10.1002/gea.10065.

Staubwasser, M., F. Sirocko, P. M. Grootes, and M. Segl. 2003. "Climate change at the 4.2 ka BP termination of the Indus valley civilization and Holocene south Asian monsoon variability." Geophysical Research Letters 30 (8). doi: 10.1029/2002GL016822.

Stoddart, S., M. Wysocki, G. Burgess, G. Barber, C. Duhig, C. Malone, and G. Mann. 1999. "The articulation of disarticulation. Preliminary thoughts on the Brochtorff Circle at Xaghra Gozo." In The loved body's corruption: contributions to the archaeological study of human mortality. , edited by J. and Pollard Downes, A, 94-105. Gloucester: Alan Sutton.

Stoddart, S. 2015. "Mediating the Dominion of Death in Prehistoric Malta." In Death Rituals, Social Order and the Archaeology of Immortality in the Ancient World. "Death Shall Have No Dominion", edited by A. C. Renfrew, M. Boyd and I. Morley, 130-7. Cambridge: Cambridge University Press.

Stoddart, S., G. Barber, C. Duhig, G. Mann, T. O'Connell, L. Lai, D. Redhouse, R. H. Tykot, and C. Malone. 2009. "Chapter 11: The Human and Animal Remains." In Mortuary customs in prehistoric Malta Excavations at the Brochtorff Circle at Xaghra (1987-94), edited by C. Malone, S. Stoddart, and A. Bonanno, and D. Trump, 315-46. Cambridge: McDonald Institute for Archaeological Research.

Trump, D. H. 1966. Skorba, Research Reports of the Society of Antiquaries of London 22. London: Society of Antiquaries.

Wang, Z.-G., X. Jin, X.-G. Bao, X.-F. Li, J.-H. Zhao, J.-H. Sun, P. Christie, and L. Li. 2014. "Intercropping Enhances Productivity and Maintains the Most Soil Fertility Properties Relative to Sole Cropping." PLOS ONE 9 (12):e113984. doi: 10.1371/journal.pone.0113984. 
Zammit, T. 1928. "Prehistoric cart-tracks in Malta." Antiquity 2 (5):18-25.

\section{Figure captions}

Figure 1 Maps showing the location and topography of the Maltese islands and sites mentioned in the text

Figure 2 A typical view from the Maltese countryside of sparse vegetation and bare rock

Figure 3 The average size (rim diameter as a proxy for overall capacity) of prehistoric potsherds from recent Fragsus project excavations on the Maltese islands, showing trend towards increasing storage capacity. The boxplots (from left to right) represent the size of storage vessels from the Ghar Dalam phase $(\mathrm{N}=7)$; Skorba phases $(\mathrm{N}=10)$; Żebbug phase $(\mathrm{N}=34)$; Mgarr phase $(\mathrm{N}=6)$; Ġgantija phase $(\mathrm{N}=96)$; Saflieni phase $(\mathrm{N}=3)$; Tarxien phase $(\mathrm{N}=34)$; Tarxien Cemetery phase $(\mathrm{N}=8)$; Borg in-Nadur phase $(\mathrm{N}=26)$. 